STUDIA I MATERIAtY

\title{
Systemy EZD w urzędach administracji publicznej w Polsce w latach 2011-2019. Rzeczywista liczba wdrożeń versus budowa marki narzędzi informatycznych
}

\section{Dorota Drzewiecka}

Uniwersytet Pedagogiczny im. Komisji Edukacji Narodowej w Krakowie / Pedagogical University of Krakow (Poland) dorota.drzewiecka@up.krakow.pl, ORCID 0000-0001-7341-0754

\section{STRESZCZENIE}

Celem artykułu jest próba ustalenia liczby rzeczywistych wdrożeń systemu EZD w podmiotach, dla których obowiązujące jest rozporządzenie Prezesa Rady Ministrów z 18 stycznia 2011 r. oraz interpretacja wyników dotychczasowych badań prowadzonych przez wybrane instytucje przy użyciu niejednorodnych metod badawczych. Badanie ma na celu pokazanie zjawiska nadinterpretowania przez producentów, a nierzadko także samych urzędników, funkcjonalności narzędzi informatycznych wspomagających pracę kancelaryjną. W artykule podjęto próbę udowodnienia przyczyny tego zjawiska. Do analizy wykorzystano dane zgromadzone na zlecenie resortu cyfryzacji z lat 2012-2015, Głównego Urzędu Statystycznego z lat 2015-2019, dwóch zrealizowanych projektów studenckich (dotyczących wdrażania systemów EZD w urzędach na terenie całego kraju oraz w województwie małopolskim) oraz protokoły kontroli przestrzegania przepisów o narodowym zasobie archiwalnym i archiwach (protokoły kontroli archiwum zakładowego) z lat 2011-2019, dotyczące jednostek administracji publicznej z terenu objętego nadzorem archiwalnym przez Archiwum Narodowe w Krakowie.
SŁOWA KLUCZOWE

systemy

informatyczne,

administracja

publiczna, Archiwum

Narodowe

w Krakowie,

systemy EZD

\section{EDM systems in public administration offices in Poland in 2011-2019. Actual number of implementations versus building a brand of IT tools}

\section{ABSTRACT}

The purpose of this paper is to attempt to determine the number of actual EDM system implementations in institutions subject to the provisions of Prime Minister's Ordinance of 18 January 2011 and to interpret the results of research conducted so far by selected institutions using heterogeneous research methods. The aim of the study is to demonstrate the phenomenon of overinterpretation of the functionality of IT tools supporting administrative work by their manufacturers and often also by the officials themselves. The article attempts to provide evidence for the causes of this phenomenon. The analysis uses data collected upon the order of the Ministry of Digitization for the years 2012-2015, the Central Statistical Office data for the years 2015-2019, two completed student projects

\section{KEYWORDS}

IT systems, public administration, National Archive in Krakow, EDM systems 
(concerning the implementation of EDM systems in offices countrywide and in Małopolskie Voivodship), and audit reports regarding compliance with the regulations on the national archival resource and archives (reports from audits of company archives) for the years 2011-2019, concerning public administration units from the area placed under archival supervision of the National Archive in Kraków.

Celem artykułu jest próba ustalenia liczby rzeczywistych wdrożeń systemu elektronicznego zarządzania dokumentacją (dalej: EZD) w polskich urzędach oraz interpretacja wyników dotychczasowych badań prowadzonych przez wybrane instytucje przy użyciu niejednorodnych metod badawczych. Badanie ma na celu pokazanie zjawiska nadinterpretowania przez producentów, a nierzadko także samych urzędników, funkcjonalności narzędzi informatycznych wspomagających pracę kancelaryjną.

Zakres przedmiotowy artykułu ogranicza się do państwowych i samorządowych jednostek organizacyjnych w Polsce, przy czym badanie zostało zawężone do podmiotów, dla których obowiązujące jest rozporządzenie Prezesa Rady Ministrów z 18 stycznia 2011 r. (dalej: Rozporządzenie PRM z 2011 r.)ำ.

Cezurą początkową jest 2011 r. - wejście w życie wspomnianego aktu prawnego, zaś datą zamykającą 2019 r. - ostatni przed wybuchem światowej pandemii COVID-19, w wyniku której większość podmiotów przeszła na tryb pracy zdalnej, co zapewne przyspieszyło rozwój informatyzacji urzędów.

Jednym z elementów, mającej już ponad dwudziestoletnią historię, informatyzacji biurowości w Polsce jest elektroniczne zarządzanie dokumentacją. Pojawiające się na przełomie XX i XXI w. akty prawne miały wpływ na funkcjonowanie przede wszystkim sektora prywatnego². Dopiero wstąpienie Polski do Unii Europejskiej i przyjęcie unijnych dyrektyw spowodowało przełom w zakresie informatyzacji, także dzięki nowym możliwościom pokrycia jej kosztów ${ }^{3}$.

1 Są to organy gminy i związków międzygminnych, organy powiatu, organy samorządu województwa i organy zespolonej administracji rządowej w województwie, a także urzędy obsługujących te organy. Zob.: Informacja nr 6 Naczelnej Dyrekcji Archiwów Państwowych z dnia 19 kwietnia 2011 r. w sprawie zakresu podmiotowego Rozporządzenia Prezesa Rady Ministrów z dnia 18 stycznia 2011 r. w sprawie instrukcji kancelaryjnej, jednolitych rzeczowych wykazów akt oraz instrukcji w sprawie organizacji i zakresu działania archiwów zakładowych (Dz. U. nr 14, poz. 67 i nr 27, poz. 140), https://www.archiwa.gov.pl/images/docs/instrukcje/06_informacja_nr_6.pdf [dostęp: 23.04.2021].

2 Ustawa z dnia 18 września 2001 r. o podpisie elektronicznym (Dz. U. 2001, nr 130, poz. 1450).

3 H. Robótka, Zarzadzanie dokumentacjq $w$ dobie informatyzacji, [w:] Zarzqdzanie dokumentacjq w instytucji. Czynniki sprzyjające i ograniczenia, Biblioteka Zarządcy Dokumentacji, t. 9, red. R. Degen i M. Jabłońska, Toruń 2020, s. 97-98. 
Za jedną z ważniejszych regulacji prawnych należy uznać ustawę o informatyzacji podmiotów realizujących zadania publiczne z 2005 r. ${ }^{4}$ Ważne były też działania zmierzające do stworzenia platformy usług elektronicznych. Projekt ten nazwano „Wrota Polski” (wcześniej „Wrota”), a jednym z jego głównych założeń było wprowadzenie „systemów do elektronicznego obiegu dokumentów z wybranej grupy najważniejszych i najczęściej występujących spraw”. W wyniku prowadzonych prac ukształtowała się elektroniczna platforma o nazwie ePUAP, przekształcona następnie w ePUAP2. Od 1 maja 2008 r. organa władzy publicznej, za pomocą platformy, mają obowiązek przyjmowania pism wpływających w postaci elektronicznej, nawet jeśli zarządzają swoją dokumentacją w sposób tradycyjny ${ }^{6}$. Ważnym elementem informatyzacji podmiotów jest wdrażanie systemów do elektronicznego zarządzania dokumentacją. Wcześniej wypracowanym rozwiązaniem było korzystanie z narzędzi informatycznych wspomagających biurowość. Plany informatyzacji państwa też uwzględniały tę kwestię, choć w nierównomiernym stopniu. W pierwszym planie wprowadzenie systemów do obsługi elektronicznego obiegu dokumentów ujęto jako jedno z najważniejszych zadań. W kolejnym punkt ciężkości został przesunięty na powstawanie i wdrażanie rejestrów publicznych, zaś o elektronicznym zarządzaniu dokumentacją napisano niewiele ${ }^{7}$. Zdaniem Haliny Robótki takie działania pokazują, że wewnętrzny obieg dokumentacji albo nie został doceniony przez autorów planu informatyzacji, albo uznano, że wewnętrzne systemy elektroniczne, których zadaniem jest obsługa biurowości elektronicznej różnych podmiotów, są trudne do zestandaryzowania. H. Robótka podkreśla także komplikacje wynikające z lokalnych przedsięwzięć urzędników i firm informatycznych dążących do wykorzystania nowych technologii w biurowości (powstawały programy służące do obsługi wybranej grupy dokumentacji, np. księgowej, lub wykonywania pojedynczych czynności kancelaryjnych, np.

4 Ustawa z dnia 17 lutego 2005 r. o informatyzacji działalności podmiotów realizujących zadania publiczne (Dz. U. 2005, nr 64, poz. 565).

5 H. Robótka, op.cit., s. 99.

6 Ustawa z dnia 14 czerwca 1960 r. Kodeks Postępowania Administracyjnego (Dz. U. 1960, nr 30, poz. 168, z późn. zm.); H. Robótka, op.cit., s. 99. Zob. także: eadem, Archiwa cyfrowe i cyfrowi archiwiści w świetle nauki i wybranych dokumentów. Rozważania czysto teoretyczne, [w:] „Archiwista cyfrowy” i infobroker - ksztatcenie, sylwetka, wyzwania, red. D. Drzewiecka i B. Drzewiecki, Kraków 2016, s. 13-24; eadem, Zarządzanie dokumentacja w podmiocie (organizacji, instytucji, u aktotwórcy). Wprowadzenie do tematyki, [w:] Zarzadzanie dokumentacja. Badania i dydaktyka, Biblioteka Zarządcy Dokumentacji, t. 7, red. R. Degen i M. Jabłońska, Toruń 2016, s. 11-36.

7 H. Robótka, Zarządzanie dokumentacja w dobie informatyzacji..., s. 101. 
rejestracji korespondencji przychodzącej i wychodzącej) ${ }^{8}$. Takie działania miały niebagatelny wpływ na wprowadzenie różnorodnych rozwiązań elektronicznej biurowości, nawet $w$ instytucjach tego samego szczebla administracji. Dopiero w Programie Zintegrowanej Informatyzacji Państwa na lata 2014-2022 za jedno z priorytetowych działań strategicznych Ministra Cyfryzacji w obszarze informatyzacji usług publicznych uznano przyjęcie standardu elektronicznego obiegu dokumentów w administracji. Działania Ministra skoncentrowane zostały na rozwoju systemu EZD RP9.

Opisane wyżej rozwiązania w zakresie rozwoju systemów elektronicznego zarządzania dokumentacją trzeba uzupełnić uwzględnieniem jeszcze innych ważnych aktów prawnych. Rozpocząć wypada od trzech aktów wykonawczych do ustawy o narodowym zasobie archiwalnym i archiwach - rozporządzeniach Ministerstwa Spraw Wewnętrznych i Administracji z 2006 r. ${ }^{10}$ Ważną i przełomową datą dla rozwijającego się w XXI w. elektronicznego zarządzania dokumentacją w jednostkach administracji publicznej w Polsce był 2011 r., bowiem 18 stycznia pojawiło się rozporządzenie Prezesa Rady Ministrów - podstawa prawna ujednolicająca narzędzia wewnętrznego zarządzania dokumentacją (wspólne normatywy kancelaryjno-archiwalne) ${ }^{11}$. Akt prawny dał określonym podmiotom publicz-

$8 \quad$ Ibidem. Zob. także: D. Drzewiecka, T. Karaś, Wdrażanie systemu elektronicznego obiegu dokumentacji w Urzędzie Miasta Krakowa - wybrane problemy, [w:] Rola archiwów w procesie wdrażania systemów elektronicznego zarzq̨dzania dokumentacją. Z doświadczeń archiwów szkół wyższych, instytucji naukowych $i$ kulturalnych oraz państwowych $i$ samorzqdowych jednostek organizacyjnych, red. A. Barciak, D. Drzewiecka i K. Pepłowska, Katowice 2018, s. 57-75.

9 Program Zintegrowanej Informatyzacji Państwa na lata 2014-2022, https://www.gov.pl/web/ cyfryzacja/program-zintegrowanej-informatyzacji-panstwa [dostęp: 26.06.2021] oraz: Serwis Rzeczypospolitej Polskiej. EZD RP - elektroniczne zarządzanie dokumentacją w administracji, archiwum.mc.gov.pl/konsultacje/program-zintegrowanej-informatyzacji-panstwa/ezd-rp-elektroniczne-zarzadzanie-dokumentacja-w-administracji [dostęp: 26.06.2021].

10 Rozporządzenie Ministra Spraw Wewnętrznych i Administracji z dnia 30 października 2006 r. w sprawie niezbędnych elementów struktury dokumentów elektronicznych (Dz. U. 2006, nr 206, poz. 1517); Rozporządzenie Ministra Spraw Wewnętrznych i Administracji z dnia 30 października 2006 r. w sprawie szczegółowego sposobu postępowania z dokumentami elektronicznymi (Dz. U. 2006, nr 206, poz. 1518); Rozporządzenie Ministra Spraw Wewnętrznych i Administracji z dnia 2 listopada 2006 r. w sprawie wymagań technicznych formatów zapisu i informatycznych nośników danych, na których utrwalono materiały archiwalne przekazywane do archiwów państwowych (Dz. U. 2006, nr 206, poz. 1519). O rozwoju informatyzacji administracji publicznych, z uwzględnieniem ważnych zamian w prawie i różnego rodzaju systemach informatycznych, zob.: D. Makowski, Archiwa a systemy informatyczne w administracji publicznej. Wstęp do problematyki, „Archeion” 2020, t. 121, s. 411-444.

11 Rozporządzenie Prezesa Rady Ministrów z dnia 18 stycznia 2011 r. w sprawie instrukcji kancelaryjnej, jednolitych rzeczowych wykazów akt oraz instrukcji w sprawie organizacji i zakresu 
nym możliwość wyboru, czy nadal będą pracować w tzw. systemie tradycyjnym, czy też przejdą na elektroniczne zarządzanie dokumentacją, a więc wdrożą system EZD ${ }^{12}$. Oba wymienione systemy uzyskały swoją definicję prawną, zgodnie z którą system tradycyjny to „system wykonywania czynności kancelaryjnych, dokumentowania przebiegu załatwiania spraw, gromadzenia i tworzenia dokumentacji w postaci nieelektronicznej, z możliwością korzystania z narzędzi informatycznych do wspomagania procesu obiegu dokumentacji w tej postaci"13. W podmiocie, który wybrał system EZD jako podstawowy, wszystkie czynności wykonywane są w ramach EZD. Tworzy się dokumentację elektroniczną, elektroniczne akta sprawy ${ }^{14}$. System EZD został zdefiniowany jako „system teleinformatyczny do elektronicznego zarządzania dokumentacją umożliwiający wykonywanie w nim czynności kancelaryjnych, dokumentowanie przebiegu załatwiania spraw oraz gromadzenie i tworzenie dokumentów elektronicznych"15.

Istotnym elementem elektronicznego zarządzania dokumentacją jest system teleinformatyczny, którego wymagania zostały uregulowane we wspomnianym już rozporządzeniu z 2006 r. o szczegółowym postępowaniu z dokumentami elektronicznymi ${ }^{16}$. Bardzo ważny i konieczny podkreślenia jest jeden fakt: jeże-

działania archiwów zakładowych (Dz. U. 2011, nr 14, poz. 67). Rozporządzenie dotyczy państwowych i samorządowych jednostek organizacyjnych. Definicję tych jednostek, zob.: E. Perłakowska, Systemy zarzq̨dzania dokumentacjq w urzędzie, [w:] G. Abgarowicz, E. Perłakowska, A. Prasal, Procedury elektronicznego zarzqdzania dokumentacja w administracji, Warszawa 2018, s. 56-57.

12 Omówienie treści Rozporządzenia z 2011 r. zob. m.in.: Wspótczesna biurowość w administracji publicznej. Komentarz do instrukcji biurowej Prezesa Rady Ministrów z 2011 r., Biblioteka Zarządcy Dokumentacji, t. 4, red. H. Robótka, Toruń 2013; E. Perłakowska, op.cit., s. 55-76; eadem, Zarzadzanie dokumentacjq w systemie tradycyjnym, [w:] G. Abgarowicz, E. Perłakowska, A. Prasal, op.cit., s. 77-127; eadem, Elektroniczne zarzqdzanie dokumentacja, [w] ibidem, s. 129-186; S. Czerniak, J. Orszulak, Dokument elektroniczny. Przewodnik i katalog dobrych praktyk, Warszawa 2017.

13 Rozporządzenie PRM z 2011 r., § 2 pkt. 14.

14 Oczywiście od podstawowego systemu można wskazać wyjątki (określane szczegółowymi hasłami z wykazu akt lub realizowane w ramach tzw. systemów dziedzinowych), ale nie to jest przedmiotem artykułu.

15 Rozporządzenie PRM z 2011 r., § 2 pkt. 13.

16 Zgodnie z § 6. Rozporządzenia Ministra Spraw Wewnętrznych i Administracji z dnia 30 października 2006 r. w sprawie szczegółowego sposobu postępowania z dokumentami elektronicznymi, system teleinformatyczny: „1) zapewnia integralność treści dokumentów i metadanych polegającą na zabezpieczeniu przed wprowadzaniem zmian, z wyjątkiem zmian wprowadzanych w ramach ustalonych i udokumentowanych procedur; 2) zabezpiecza przed wprowadzaniem zmian w dokumentach spraw załatwionych; 3) zabezpiecza przed usunięciem dokumentów z systemu, z wyjątkiem udokumentowanych czynności dokonywanych w ramach ustalo- 
li system nie spełnia wymienionych warunków, to podmiot nie może zarządzać dokumentami elektronicznymi. Oznacza to także, że nie może dokumentować spraw w postaci elektronicznej ${ }^{17}$.

Elektroniczne zarządzanie dokumentacją wiąże się z tym, że pracownicy wykonują powierzone im zadania związane z realizacją spraw w środowisku systemu teleinformatycznego bez potrzeby korzystania z dokumentacji w jej pierwotnej postaci nieelektronicznej, o ile taka w ogóle była. System EZD nie ma charakteru wspomagającego w kancelarii tradycyjnej, tylko charakter podstawowy. Oznacza to, że całość dokumentacji jest prowadzona i przechowywana w systemie w postaci elektronicznej ${ }^{18}$. Jak słusznie zauważyła Ewa Perłakowska, „jedynie pracując w ramach takiego systemu, podmiot może mieć pewność, że prawidłowo wdrożył elektroniczne zarządzanie dokumentacją oraz zapewnia pewność, wiarygodność

nych procedur usuwania dokumentów: a) dla których upłynął okres przechowywania ustalony w wykazie akt, b) mylnie zapisanych, c) mogących stanowią zagrożenie dla prawidłowego funkcjonowania systemu, d) których usunięcie wymagane jest na podstawie przepisu prawa, prawomocnego orzeczenia sądu lub ostatecznej decyzji organu administracji; 4) zapewnia stały i skuteczny dostęp do dokumentów oraz ich wyszukiwanie; 5) umożliwia odczytanie metadanych dla każdego dokumentu; 6) identyfikuje użytkowników i dokumentuje dokonywane przez nich zmiany w dokumentach i metadanych; 7) zapewnia kontrolę dostępu poszczególnych użytkowników do dokumentów i metadanych; 8) umożliwia odczytanie bez zniekształceń treści dokumentów wytworzonych przez podmiot, w którym działa system; 9) zachowuje dokumenty i metadane w strukturze określonej w przepisach wydanych na podstawie art. 5 ust. 2a ustawy, łącznie z możliwością prezentacji tej struktury; 10) zapewnia odtworzenie przebiegu załatwiania i rozstrzygania spraw; 11) wspomaga czynności związane z klasyfikowaniem i kwalifikowaniem oraz grupowaniem dokumentów w akta spraw na podstawie wykazu akt; 12) wspomaga i dokumentuje proces brakowania dokumentów stanowiących dokumentację niearchiwalną, w tym: a) wyodrębnia automatycznie dokumenty przeznaczone do brakowania, b) przygotowuje automatycznie spis dokumentacji niearchiwalnej; 13) wspomaga czynności związane z przygotowaniem dokumentów stanowiących materiały archiwalne i ich metadanych do przekazania do archiwum państwowego, w tym: a) wyodrębnia automatycznie dokumenty przeznaczone do przekazania, b) przygotowuje automatycznie spis zdawczo-odbiorczy, w postaci dokumentu elektronicznego, c) eksportuje dokumenty i ich metadane, d) oznacza dokumenty przekazane do archiwum państwowego w sposób umożliwiający ich odróżnienie od dokumentów nieprzekazanych; 14) umożliwia przesyłanie dokumentów do innych systemów teleinformatycznych, w szczególności przez: a) eksport dokumentów i ich metadanych lub wskazań na te metadane oraz danych dokumentujących dokonane zmiany, o których mowa w pkt 6, z zachowaniem powiązań pomiędzy tymi dokumentami i metadanymi, b) zapisywanie wyeksportowanych metadanych w formacie XML”. Dla dokumentów ewidencjonowanych spełnia funkcję archiwum zakładowego lub składnicy akt.

17 E. Perłakowska, Systemy zarzq̨dzania dokumentacją w urzędzie..., s. 71.

18 Archiwa Państwowe. EZD informacje ogólne, https://www.archiwa.gov.pl/pl/772-ezd-informacje-ogólne [dostęp: 20.04.2021]. 
i niezmienność w czasie w obsłudze dokumentacji19". Charakter wspomagający mogą mieć jedynie narzędzia informatyczne w systemie tradycyjnym, służące m.in. do przyjmowania, rejestracji i obiegu korespondencji. System EZD nazywany jest potocznie systemem klasy EZD. Takie określenie, choć jest spotykane coraz częściej, nie jest unormowane ani zdefiniowane na gruncie prawa, co może skutkować doprowadzeniem do terminologicznego chaosu ${ }^{20}$.

W 2014 r. w trakcie V Wiosennych Spotkań Archiwalnych autorka niniejszego artykułu wygłosiła referat pt. „Mapa topograficzna systemów EZD w Polsce”21. Kwerenda, prowadzona wówczas głównie w oparciu o zasoby internetowe, pozwoliła na wysunięcie niepokojących wniosków. Poza systemem EZD autorstwa Podlaskiego Urzędu Wojewódzkiego ciężko było znaleźć system spełniający warunki określone we wspomnianych rozporządzeniach. Z kolei wiele komercyjnych firm, reklamując swój produkt, określało go mianem systemu EZD, choć często były to jedynie narzędzia wspomagające wykonywanie wybranych czynności kancelaryjnych. Niestety nie zawsze był to zabieg marketingowy wynikający z chęci sprzedaży produktu. Okazało się, że pracownicy firmy nie dostrzegali różnicy między określonym prawem elektronicznym zarządzaniem dokumentacją a wspomaganiem wybranych czynności kancelaryjnych ${ }^{22}$.

Przedstawione wówczas efekty rekonesansu badawczego należy znacząco uzupełnić. Postanowiono ponownie zweryfikować dane dotyczące rzeczywistych wdrożeń systemów elektronicznego zarządzania dokumentacją. Po pierwsze, przeanalizowano wyniki badań ankietowych prowadzonych na zlecenie resortu cyfryzacji, ważnych z punktu widzenia rozwoju informatyzacji urzędów w Pol$\mathrm{sce}^{23}$. Choć badania te bezsprzecznie uznać należy za wartościowe, niestety uzy-

19 E. Perłakowska, Elektroniczne zarządzanie dokumentacją..., s. 129.

20 Ibidem. Zob. także: D. Drzewiecka, [rec.:] Grzegorz Abgarowicz, Ewa Perłakowska, Artur Prasal, Procedury elektronicznego zarządzania dokumentacja w administracji, Wydawnictwo C.H. Beck, Warszawa 2018, ss. 322, „Archeion” 2019, t. 120, s. 408.

21 Prezentacja wraz z komentarzem dostępne są na stronie: ResearchGate. Dorota Drzewiecka, https://www.researchgate.net/profile/Dorota-Drzewiecka [dostęp: 26.06.2021].

22 DMS, EZD, eSOD - różne nazwy, jeden system, www.progmate.pl/pl/articles/differentnames [dostęp: 25.01.2021].

23 Wpływ cyfryzacji na działanie urzędów administracji publicznej w Polsce w 2012 r. - badanie na zlecenie Ministerstwa Administracji i Cyfryzacji przez firmę Partner in Business Strategies, październik 2012 r., https://dane.gov.pl/media/resources/20140505/PBSMACCyfryzacjafullPL-2012.pdf [dostęp: 25.01.2021]. Te same badania powtórzono w grudniu 2013 r. (https://dane.gov.pl/media/resources/20140502/PBSMACCyfryzacja11122013.pdf [dostęp: 25.01.2021]) i 2014 r. (https://dane.gov.pl/media/resources/20150227/PBSMACCyfryzacjaFIN2014.pdf [dostęp: 25.01.2021]). W 2015 r. podobne badanie zostało wykonane przez 
skane rezultaty często nie są miarodajne. Badania dotyczyły urzędów administracji państwowej (w tym rządowej) i samorządowej. Jednak na przestrzeni lat nie zawsze te same podmioty (i w podobnej ilości) odpowiedziały na ankietę.

Jedno z pytań stawianych w kwestionariuszu brzmiało: Czy Urząd korzysta z systemu Elektronicznego Zarządzania Dokumentacją (EZD)? W 2011 r. badanie przeprowadzone we wszystkich urzędach dało wynik: TAK 41\%, NIE 59\% (n=1601). Rok później wskaźnik ten poprawił się: 46\% urzędów zadeklarowało korzystanie z systemu EZD, zaś 54\% udzieliło odpowiedzi negatywnej ( $\mathrm{n}=1556)$. W 2014 r., spośród 1644 podmiotów, które odpowiedziały na badanie, 42\% zadeklarowało korzystanie z EZD, zaś 58\% udzieliło odpowiedzi negatywnej. Rok później odsetek ten utrzymał się na tym samym poziomie (zob. wykres 1). Choć badanie nie pokazuje tendencji wzrostowej w liczbie wdrożeń systemów EZD, nie można jednoznacznie stwierdzić, że tak nie było. Mimo, iż badanie skierowane było do jednorodnej grupy podmiotów - określonych Rozporządzeniem PRM z 2011 r., trzeba wziąć pod uwagę różnorodność urzędów uczestniczących w kolejnych edycjach badania. Nie zawsze bowiem te same podmioty odpowiedziały na ankietę, o czym świadczy także liczba respondentów w poszczególnych latach. Potwierdzeniem tej tezy jest także zapis paragrafu 1.4 instrukcji kancelaryjnej będącej załącznikiem do Rozporządzenia PRM z 2011 r., który jednoznacznie zabrania podmiotom $\mathrm{z}$ wdrożonym systemem EZD powrotu do tradycyjnego sposobu zarządzania dokumentacją. Konkludując, można stwierdzić, że badania przeprowadzone i opublikowane przez jedno z ministerstw nie są wiarygodne.

Spośród urzędów, które zadeklarowały korzystanie z systemu EZD, najwyższy odsetek stanowiły urzędy administracji państwowej, w tym rządowej. Z kolei wśród podmiotów samorządowych system EZD cieszył się największą popularnością w urzędach powiatowych. Najgorzej w tym zakresie wypadły urzędy gminne.

ASM - Centrum Badan i Analiz Rynku na zlecenie Ministerstwa Cyfryzacji (https://dane.gov. pl/media/resources/20160907/raportwplywcyfryzacjinadzialanieurzedowadministracjipublicznejwpolscew2015r.-wcag0.pdf [dostęp: 25.01.2021]). 
Wykres 1. Korzystanie przez urzędy z systemu elektronicznego zarządzania dokumentacją w latach 2011-2012 i 2014-2015

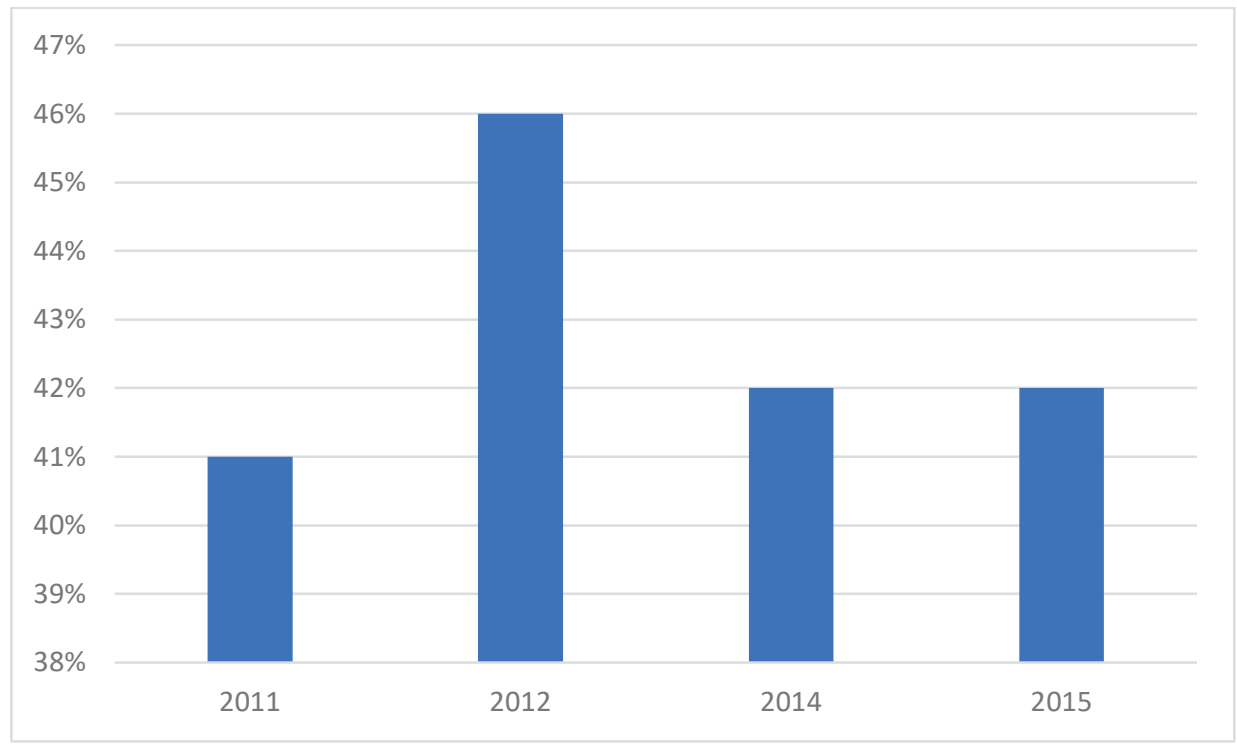

Źródło: zob. przyp. 23.

Wykres 2. Korzystanie przez urzędy z systemu elektronicznego zarządzania dokumentacją (EZD) w latach 2012 i 2014-2015

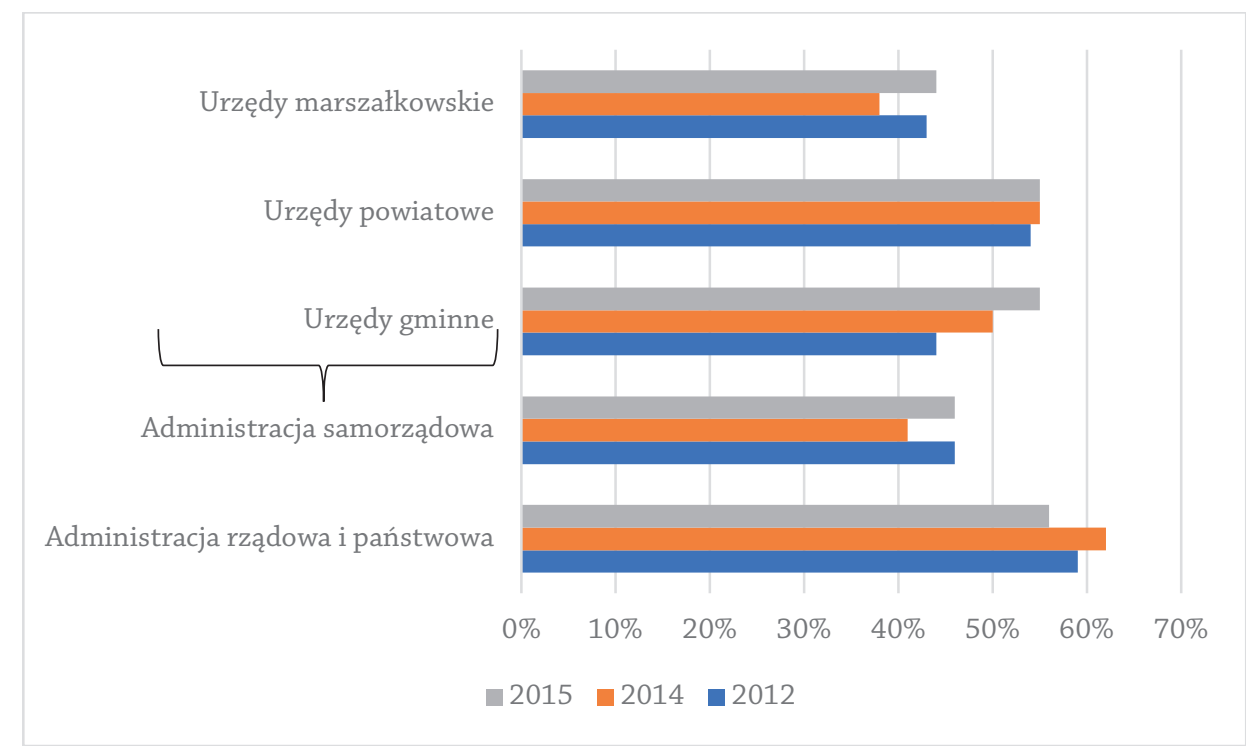

Źródło: zob. przyp. 23. 
W ramach prowadzonych badań poproszono w wskazanie podstawowego rodzaju systemu wykonywania czynności. Wyróżniono trzy rodzaje: system tradycyjny - wyłącznie w postaci nieelektronicznej, system tradycyjny wspomagany wykorzystaniem narzędzi teleinformatycznych oraz system EZD. Analizując liczbę wskazań tego pierwszego, widoczny jest spadek między 2012 a 2015 r., co w procesie rozwijającej się informatyzacji urzędów jest zjawiskiem pozytywnym.

Wykres 3. System tradycyjny (w postaci nieelektronicznej) stosowany w urzędach jako podstawowy sposób dokumentowania przebiegu załatwiania i rozstrzygania spraw w latach 2012-2015

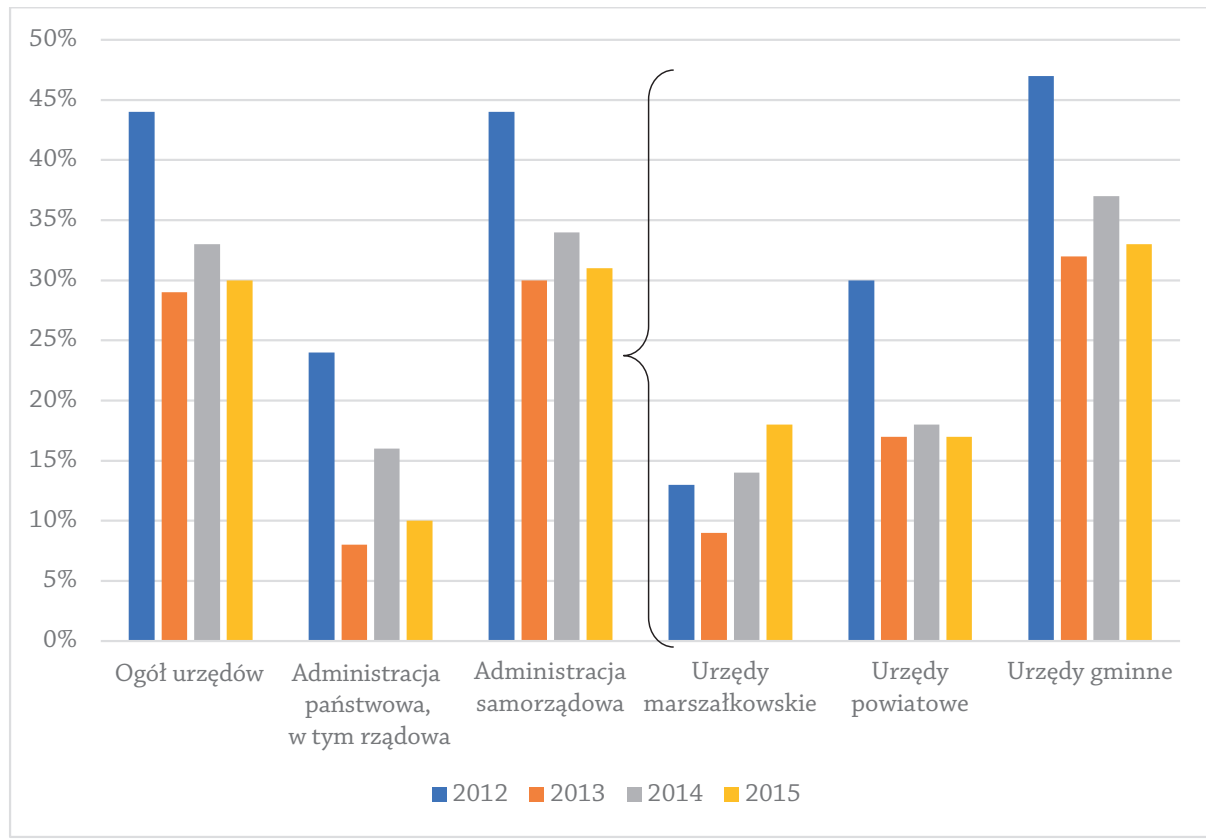

Źródło: zob. przyp. 23.

Inaczej wygląda zjawisko stosowania systemu tradycyjnego jako podstawowego, ale przy wykorzystaniu różnego rodzaju narzędzi teleinformatycznych. Biorąc pod uwagę ogół urzędów, odnotować można niewielki wzrost, potwierdzony w grupie urzędów administracji samorządowej - powiatowych i gminnych. 
Wykres 4. System tradycyjny wspomagany wykorzystaniem narzędzi teleinformatycznych stosowany w urzędach jako podstawowy sposób dokumentowania przebiegu załatwiania i rozstrzygania spraw w latach 2012-2015

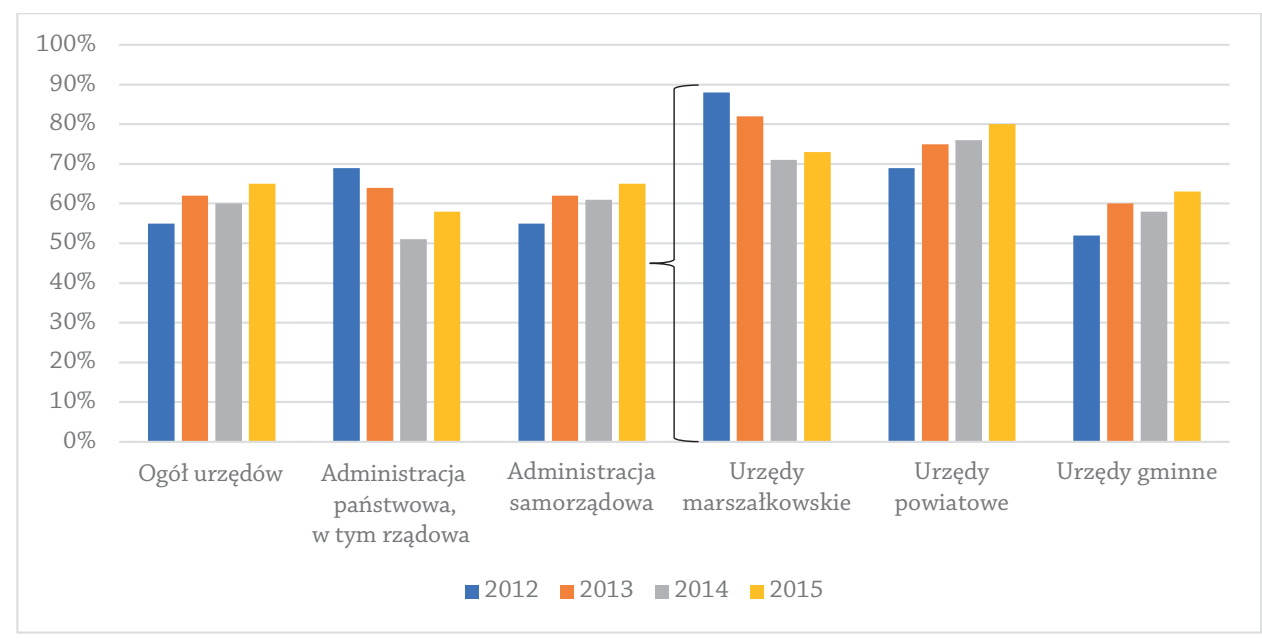

Źródło: zob. przyp. 23.

Jeszcze inne są wyniki stosowania systemu EZD jako podstawowego sposobu wykonywania czynności kancelaryjnych. Pozycję lidera osiągnęła grupa podmiotów administracji państwowej, w tym rządowej. To zjawisko nie powinno dziwić z uwagi na stworzenie systemu EZD Podlaskiego Urzędu Wojewódzkiego, który jest wdrożony w większości urzędów wojewódzkich, a liczba wdrożeń w innych podmiotach państwowych stale rośnie ${ }^{24}$.

Badania prowadzone na zlecenie resortu cyfryzacji pozwalają także na uchwycenie skali wdrożeń według podziału na województwa. Wysokie wskaźniki w tym zakresie osiągnęły województwa dolnośląskie, lubelskie, mazowieckie i śląskie.

24 Elektroniczne zarządzanie dokumentacją. Partnerzy w liczbach, https://ezd.gov.pl/www/ezd/ partnerzy [dostęp: 18.06.2021]. 
Wykres 5. System elektronicznego zarządzania dokumentacją (EZD) stosowany w urzędach jako podstawowy sposób dokumentowania przebiegu załatwiania i rozstrzygania spraw w latach 2012-2015

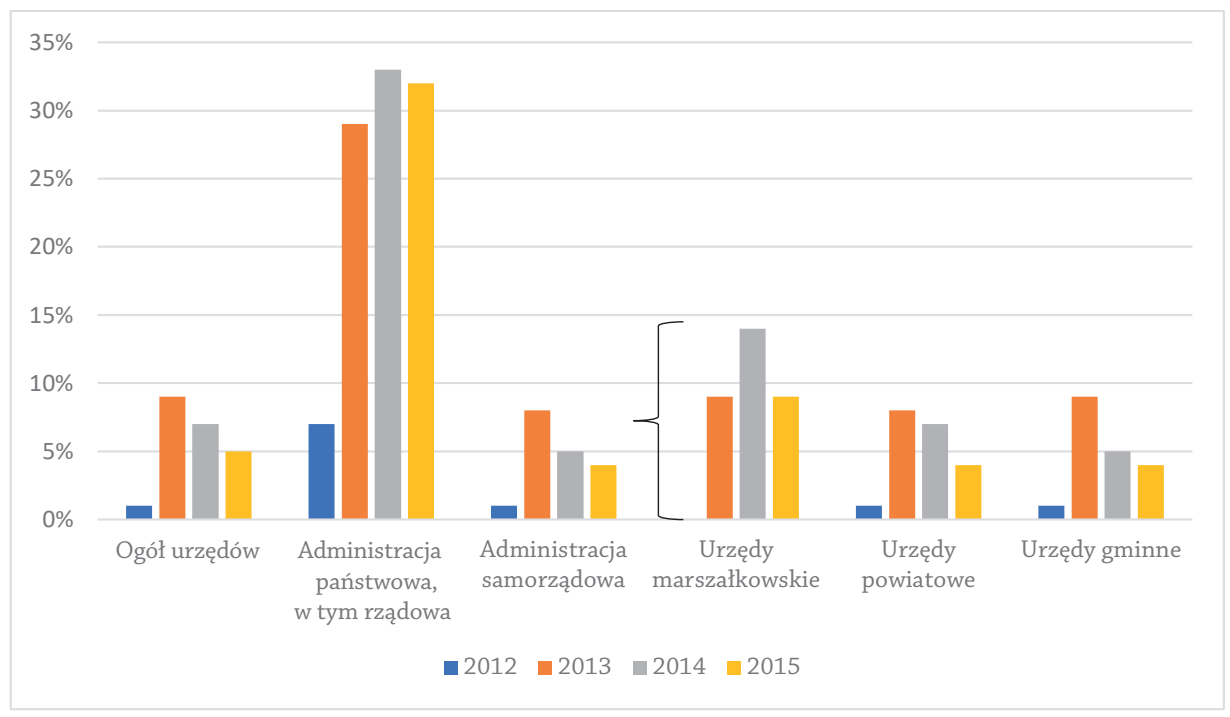

Źródło: zob. przyp. 23.

Wykres 6. Korzystanie przez urzędy z systemu elektronicznego zarządzania dokumentacją (EZD) w latach 2012 i 2014-2015, z podziałem na województwa

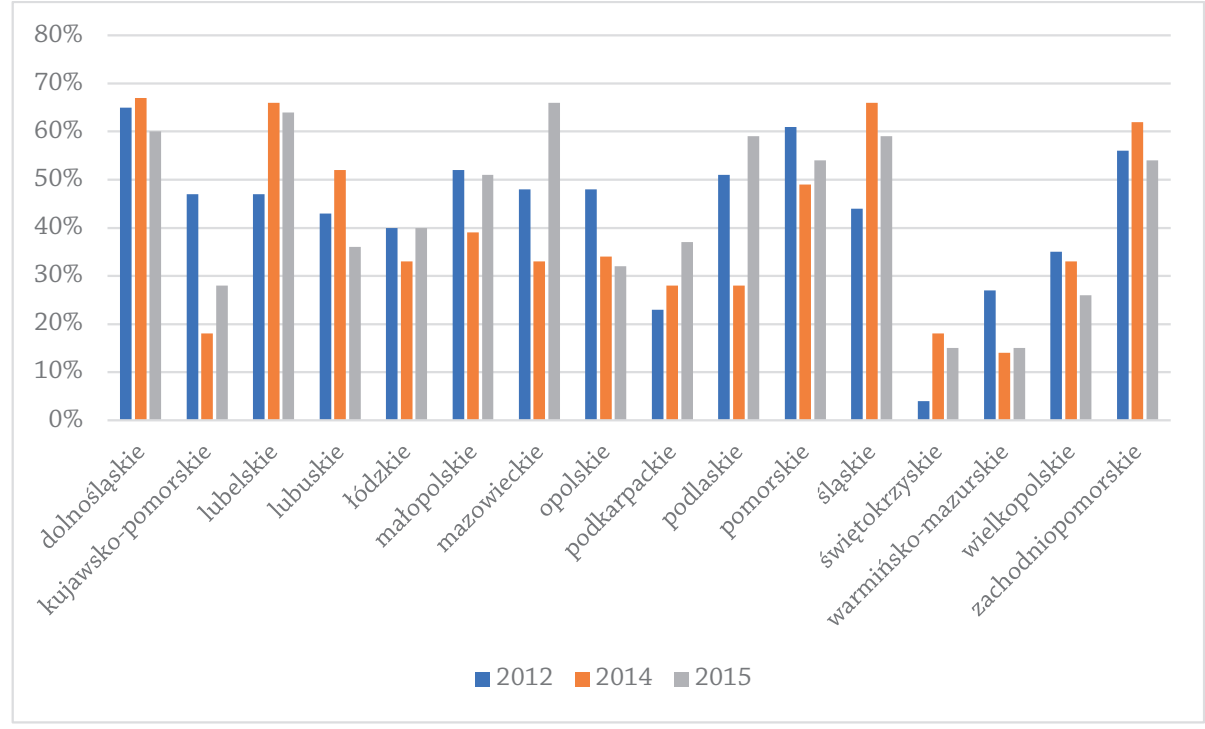

Źródło: zob. przyp. 23. 
Podsumowując, należy stwierdzić, że prym wiodą rozwiązania polegające na wykonywaniu czynności kancelaryjnych w systemie tradycyjnym, który jest wspomagany różnego typu narzędziami teleinformatycznymi, co obrazuje wykres 7. Niestety nie daje on możliwości wysnucia miarodajnych wniosków dotyczących stosowania systemów na przestrzeni lat. Spadek niemal o połowę (z 9\% do 5\%) udziału urzędów stosujących EZD może być wynikiem doboru grupy badawczej, w której znalazły się urzędy niewystępujące w poprzednich edycjach badania (zobacz komentarz do wykresu 1.) ${ }^{25}$.

Wykres 7. Rodzaje systemów wykonywania czynności kancelaryjnych stosowanych w urzędach jako podstawowe sposoby dokumentowania przebiegu załatwiania i rozstrzygania spraw w latach 2013-2015 (dane dla urzędów ogółem)

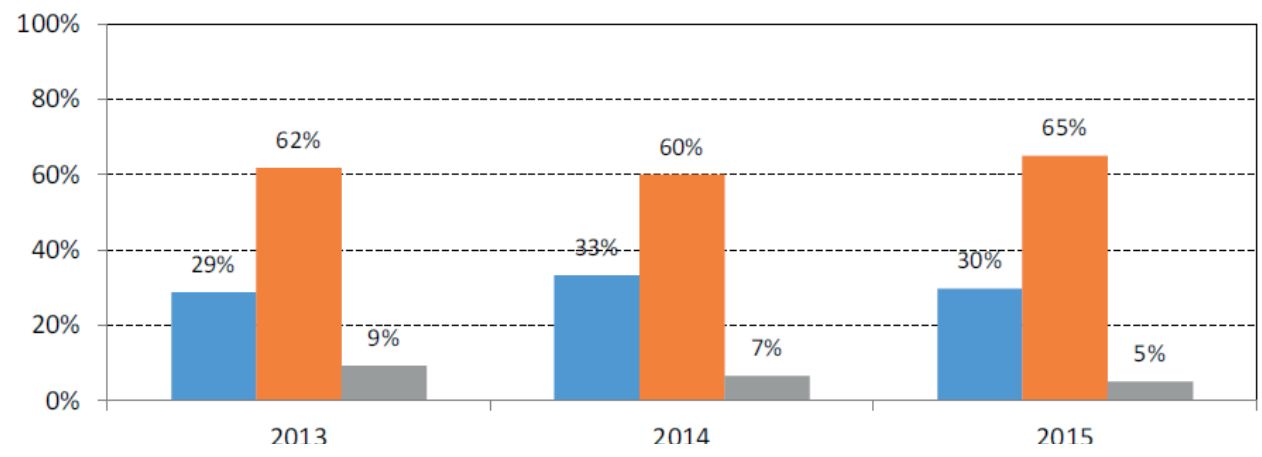

Źródło: zob. przyp. 25.

Nieco inne są wyniki badania przeprowadzonego przez Główny Urząd Statystyczny ${ }^{26}$. Wskazują one, że w 2015 r. 49,6\% ogółu urzędów korzystało z systemu elektronicznego zarządzania dokumentacją, z czego 11,6\% wskazywało go jako podstawowy sposób dokumentowania przebiegu załatwiania i rozstrzygania

25 Wpływ cyfryzacji na działanie urzędów administracji publicznej w Polsce w 2015 r. ..., s. 80.

26 Główny Urząd Statystyczny, Społeczeństwo informacyjne w Polsce. Wyniki badań statystycznych z lat 2014-2018, https://stat.gov.pl/obszary-tematyczne/nauka-i-technika-spoleczenstwo-informacyjne/spoleczenstwo-informacyjne/spoleczenstwo-informacyjne-w-polsce-wyniki-badan-statystycznych-z-lat-2014-2018,1,12.html [dostęp: 12.04.2021] i Główny Urząd Statystyczny, Społeczeństwo informacyjne w Polsce w 2020 r., https://stat.gov.pl/obszary-tematyczne/ nauka-i-technika-spoleczenstwo-informacyjne/spoleczenstwo-informacyjne/spoleczenstwo-informacyjne-w-polsce-w-2020-roku,1,14.html [dostęp: 12.04.2021]. 
spraw $^{27}$. W 2016 r. już ponad połowa badanych podmiotów korzystała z systemu EZD, a rok później odsetek ten wzrósł. Z tej liczby wyłonił się także obraz niespełna 20\% urzędów korzystających z EZD jako podstawowego sposobu dokumentowania spraw ${ }^{28}$. Badanie dotyczące wykorzystania systemu EZD w jednostkach administracji publicznej zostało powtórzone przez Główny Urząd Statystyczny także w 2019 r. ${ }^{29}$ Nadal zaobserwować można wzrost odsetka urzędów deklarujących korzystanie z EZD oraz wskazujących ten system jako podstawowy sposób dokumentowania przebiegu załatwiania i rozstrzygania spraw. Szczególny wzrost (niespełna 10\%) nastąpił w 2018 r.

Zbieżne są wyniki badań w kwestii rodzajów urzędów stosujących EZD częściej z systemów tych korzystają jednostki administracji państwowej niż samorządowej (zob. wykres 10). Należy także zauważyć, że wielkość wskaźnika wykorzystania EZD jako podstawowego sposobu dokumentowania przebiegu załatwiania i rozstrzygania spraw różniła się znacznie pomiędzy urzędami administracji państwowej a samorządowej.

27 Najwięcej urzędów korzystających z EZD odnotowano w województwie śląskim - 79,9\%, zaś najniższy odsetek dotyczył województwa warmińsko-mazurskiego - 19,2\%, zob.: Główny Urząd Statystyczny, Społeczeństwo informacyjne w Polsce. Wyniki badań statystycznych z lat 2014-2018, s. 42.

28 Badanie to pokazało duże zróżnicowanie w ujęciu terytorialnym. Najwyższy odsetek urzędów stosujących EZD odnotowano w województwie podlaskim (2016 r.: 90,9\%, 2017 r.: 95\%), zaś najniższy w województwie warmińsko-mazurskim (2016 i 2017 r.: 21,7\%). Podmioty stosujące EZD jako system podstawowy dominowały w województwie pomorskim (2016 r.: 31,7\%, 2017 r.: 32,1\%), zaś na ostatnim miejscu uplasowało się województwo podlaskie (2016 r.: 7,3\%, 2017 r.: 8,7\%) - pomimo faktu, że województwo podlaskie znalazło się w czołówce jednostek korzystających z EZD. Zob. ibidem, s. 39.

29 Także i to badanie pokazało duże zróżnicowanie w ujęciu terytorialnym. Najwyższy odsetek urzędów stosujących EZD odnotowano w województwie podlaskim (2019 r.: 97\%), zaś najniższy w województwie lubuskim (2019 r.: 51,6\%). Podmioty stosujące EZD jako system podstawowy dominowały w województwie mazowieckim (41,5\%), zaś na ostatnim miejscu uplasowało się województwo kujawsko-pomorskie (18,6\%). Zob. Główny Urząd Statystyczny, Społeczeństwo informacyjne w Polsce w 2020 r., https://stat.gov.pl/obszary-tematyczne/nauka-i-technika-spoleczenstwo-informacyjne/spoleczenstwo-informacyjne/spoleczenstwo-informacyjne-w-polsce-w-2020-roku,1,14.html [dostęp: 12.04.2021], s. 51. 
Wykres 8. Jednostki administracji publicznej korzystające z EZD (w \% ogółu jednostek) i EZD jako podstawowego sposobu dokumentowania (w \% jednostek korzystających z EZD) w latach 2015-2019

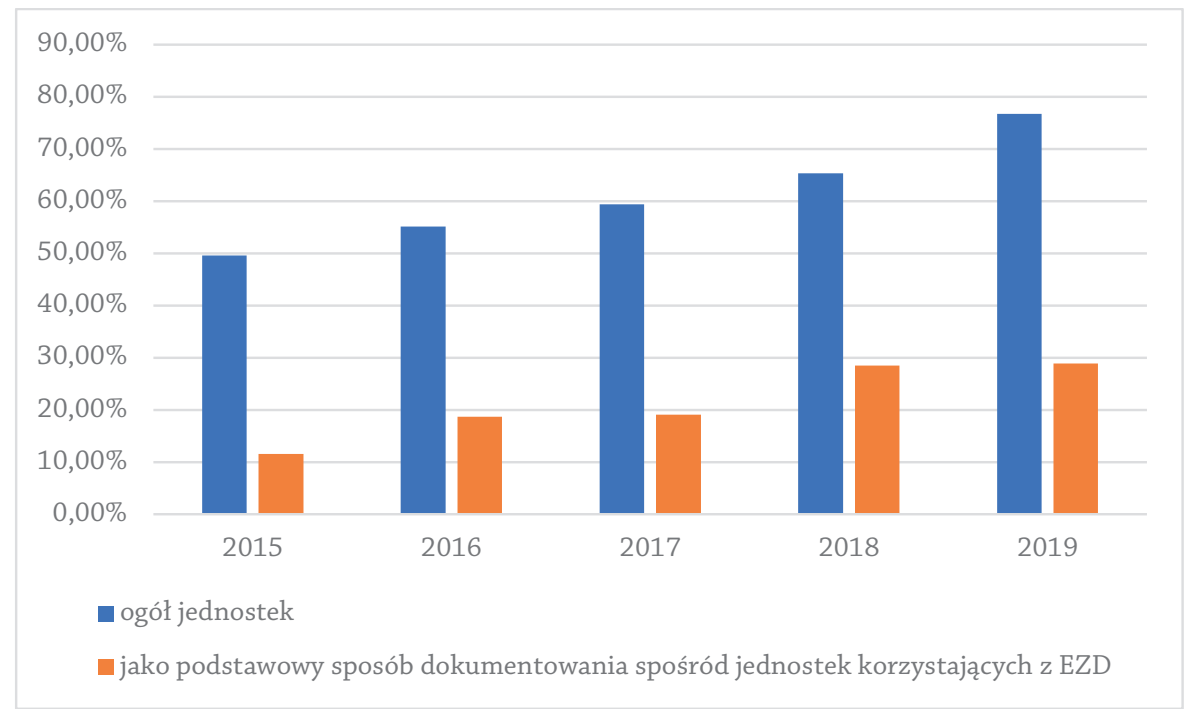

Źródło: zob. przyp. 26.

Wykres 9. Jednostki administracji państwowej (w tym rządowej) korzystające z EZD (w \% ogółu jednostek) i EZD jako podstawowego sposobu dokumentowania (w \% jednostek korzystających z EZD) w latach 2016-2019

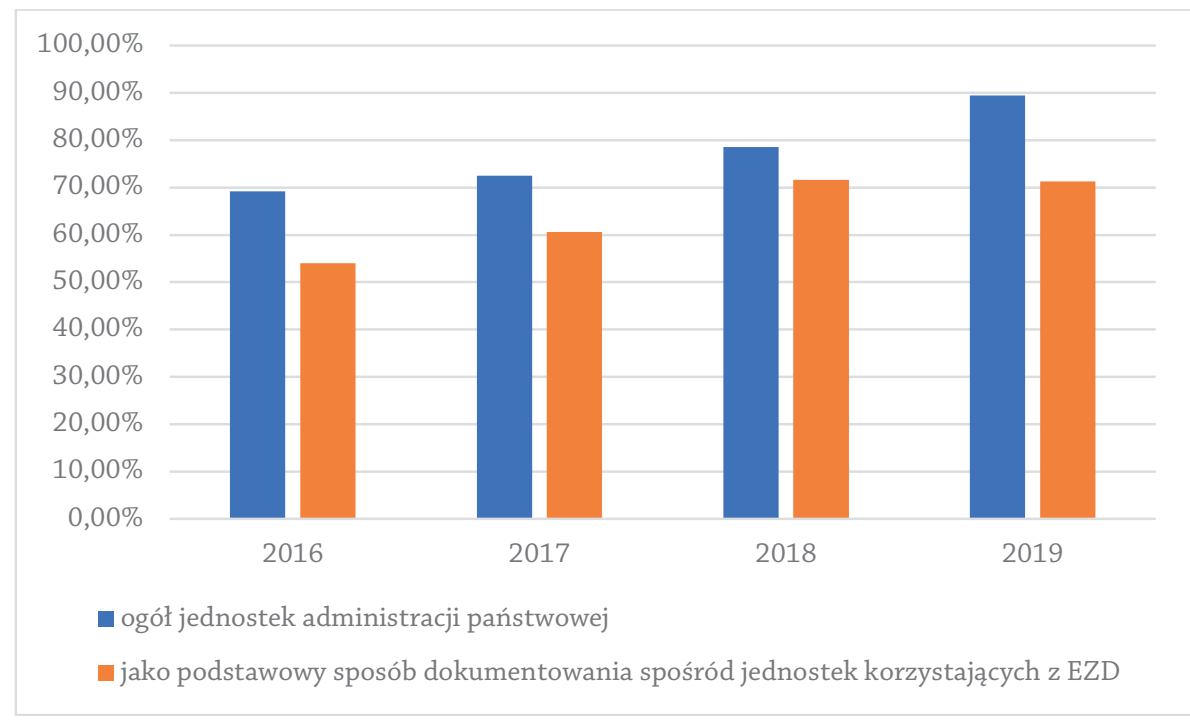

Źródło: zob. przyp. 26. 
Wykres 10. Jednostki administracji samorządowej korzystające z EZD (w \% ogółu jednostek) i EZD jako podstawowego sposobu dokumentowania (w \% jednostek korzystających z EZD) w latach 2016-2019

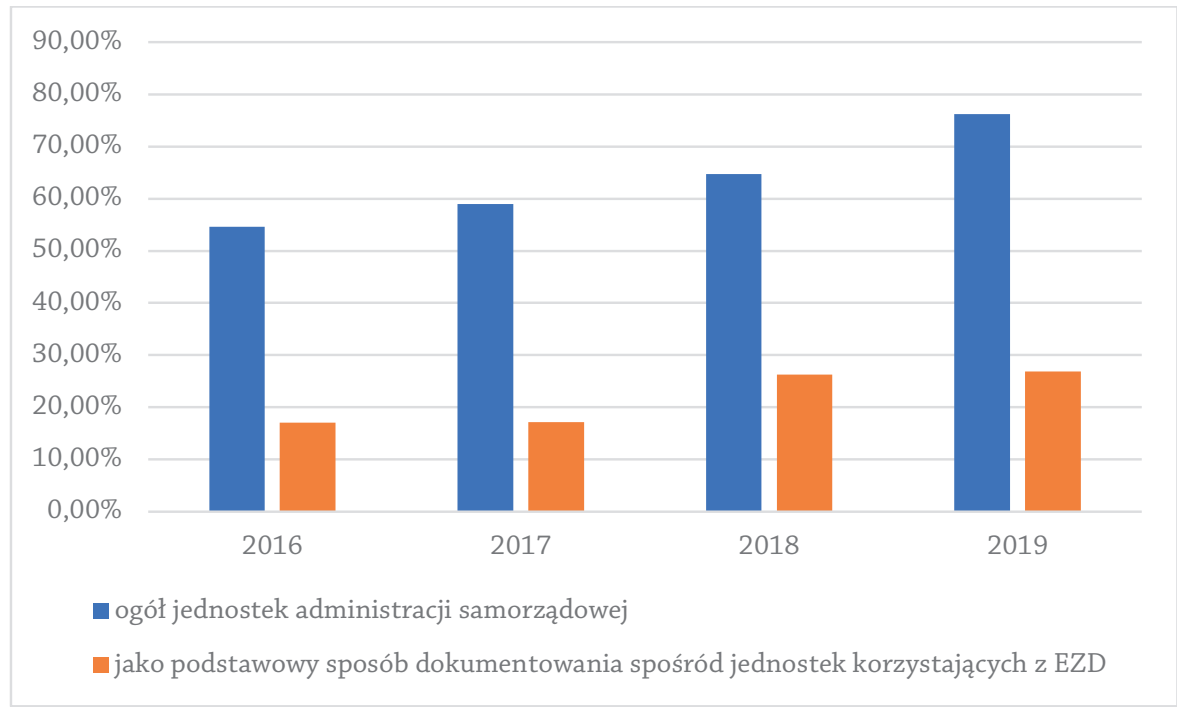

Źródło: zob. przyp. 26.

Wykres 11. Jednostki administracji samorządowej korzystające z EZD (w \% ogółu jednostek) i EZD jako podstawowego sposobu dokumentowania (w \% jednostek korzystających z EZD)

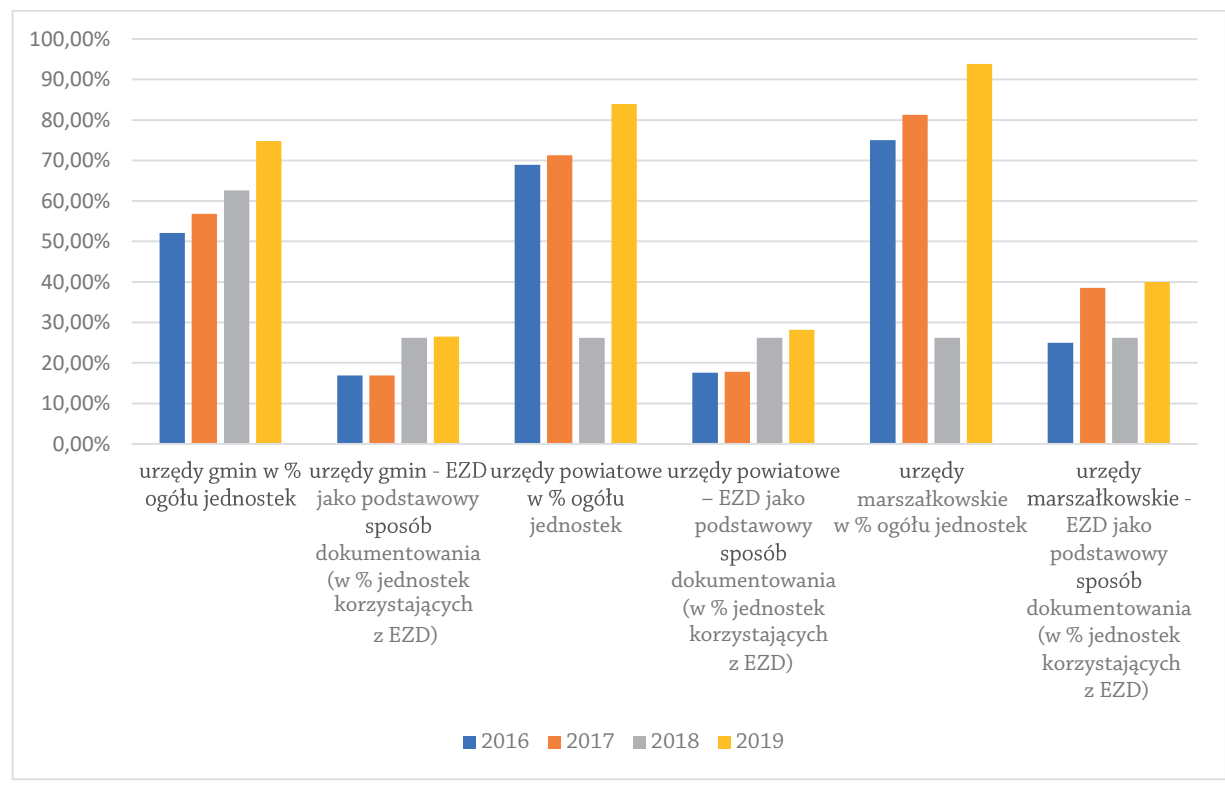

Źródło: zob. przyp. 26. 
System EZD zyskał największą popularność wśród urzędów marszałkowskich $-93,8 \%$, natomiast największy wzrost udziału jednostek stosujących ten system w skali roku odnotowano w urzędach gmin (o 12,2 p. proc.). Elektroniczne zarządzanie dokumentacją będące podstawowym sposobem dokumentowania spraw cieszy się największą popularnością także w urzędach marszałkowskich, najmniejszą zaś w gminach.

Kolejnych danych dotyczących liczby wdrożeń systemów EZD w polskich urzędach dostarczają wyniki dwóch projektów przeprowadzonych przez studentów kierunku archiwistyka, zarządzanie dokumentacją i infobrokerstwo Uniwersytetu Pedagogicznego im. KEN w Krakowie. Celem pierwszego, realizowanego w semestrze letnim roku akademickiego 2018/2019, była ocena poziomu wdrażania i funkcjonowanie systemów EZD w jednostkach podmiotowo określonych przez Rozporządzenie z 2011 r. na terytorium Rzeczpospolitej Polskiej. We wszystkich województwach wytypowano kilkadziesiąt reprezentatywnych urzędów. Do każdego, w trybie dostępu do informacji publicznej ${ }^{30}$, wysłano wniosek zawierający krótki kwestionariusz:

Czy w podmiocie funkcjonuje system EZD (zgodny z definicją z Rozporządzenia PRM z 18 stycznia 2011 r.), jeśli tak to od kiedy?

Jeżeli w podmiocie nie funkcjonuje system EZD, to czy istnieją narzędzia informatyczne wspomagające wykonywanie czynności kancelaryjnych (np. rejestr korespondencji przychodzącej i/lub wychodzącej, spis spraw)?

Proszę podać nazwę producenta systemu EZD (zob. punkt 1) lub narzędzia informatycznego wspomagającego wykonywanie czynności kancelaryjnych (zob. punkt 2).

$\mathrm{Na}$ podstawie jakich wewnętrznych regulacji podmiotu funkcjonuje system EZD lub inne narzędzia informatyczne wspomagające wykonywanie czynności kancelaryjnych (numer zarządzenia kierownika podmiotu dotyczącego wprowadzenia systemu EZD, odnośnik do dziennika urzędowego)?

Czy w systemie EZD funkcjonuje moduł archiwum zakładowego, jeśli nie, to czy działają inne narzędzia informatyczne wspomagające archiwum zakładowe?

Jakie klasy z jednolitego rzeczowego wykazu akt prowadzone są w systemie EZD (proszę wskazać maks. 5 przykładów)?

30 Ustawa o dostępie do informacji publicznej z dnia 6 września 2001 r. (Dz. U. 2001, nr 112, poz. 1198). 
Poniższa tabela zawiera zestawienie zebranych odpowiedzi dotyczących liczby wdrożeń systemu EZD ${ }^{31}$.

Tabela 1. Wdrożenia systemu EZD w urzędach administracji publicznej w Polsce. Stan na 2019 r.

\begin{tabular}{|c|c|c|c|c|c|}
\hline Województwo & $\begin{array}{c}\text { Liczba } \\
\text { otrzymanych } \\
\text { odpowiedzi }\end{array}$ & EZD & $\begin{array}{c}\text { EZD - } \\
\text { trwają } \\
\text { wdrożenia }\end{array}$ & $\begin{array}{c}\text { EZD jako } \\
\text { wspomagający }\end{array}$ & $\begin{array}{l}\text { EZD - inne } \\
\text { odpowiedzi }\end{array}$ \\
\hline dolnośląskie & 38 & 4 & - & 2 & - \\
\hline $\begin{array}{l}\text { kujawsko- } \\
\text { pomorskie }\end{array}$ & 38 & 7 & 5 & 2 & - \\
\hline lubelskie & 35 & 13 & - & 3 & $\begin{array}{c}1 \text { - system } \\
\text { EZD niezgodny } \\
\text { z definicją } \\
\text { z } 2011 \text { r. }\end{array}$ \\
\hline lubuskie & 24 & 1 & - & - & - \\
\hline łódzkie & 35 & 2 & - & 1 & - \\
\hline małopolskie & 40 & 12 & 3 & 1 & - \\
\hline mazowieckie & 56 & 42 & 3 & 1 & $\begin{array}{c}1 \text { - system } \\
\text { EZD niezgodny } \\
\text { z definicją } \\
\text { z } 2011 \text { r. }\end{array}$ \\
\hline opolskie & 26 & 4 & 1 & 2 & - \\
\hline podkarpackie & 20 & 3 & - & - & - \\
\hline podlaskie & 26 & 26 & - & - & - \\
\hline pomorskie & 40 & 11 & - & 2 & - \\
\hline śląskie & 33 & 13 & - & 2 & - \\
\hline świętokrzyskie & 20 & 5 & 2 & 1 & - \\
\hline $\begin{array}{l}\text { warmińsko- } \\
\text { mazurskie }\end{array}$ & 72 & 11 & - & - & - \\
\hline wielkopolskie & 18 & 2 & - & - & - \\
\hline $\begin{array}{l}\text { zachodniopo- } \\
\text { morskie }\end{array}$ & 35 & 8 & - & - & - \\
\hline
\end{tabular}

Źródło: Zob. przyp. 33.

31 W tabeli nie uwzględniono licznie udzielanych odpowiedzi deklarujących stosowanie narzędzi informatycznych wspomagających pracę biurową. 
W oparciu o nadesłane odpowiedzi ukształtował się obraz lidera wśród regionów. Badanie pokazało, że w województwie mazowieckim są 42 podmioty stosujące system EZD. Miejsce drugie przypadło woj. podlaskiemu z liczbą 26. Ważnym w ankiecie było pytanie dotyczące producenta sytemu. Dzięki uzyskanym odpowiedziom możliwa była analiza stron internetowych poszczególnych firm. Wykazała ona, że system, w którego nazwie występuje termin EZD, niekoniecznie spełnia warunki określone w rozporządzeniu z 2006 r. Jako jeden z przykładów warto podać system SIDAS EZD, który jest idealnym rozwiązaniem dla podmiotów pracujących w tzw. systemie tradycyjnym, a jednocześnie pragnących mieć wsparcie w postaci systemu informatycznego. Zresztą wśród nadesłanych odpowiedzi system SIDAS pojawiał się zdecydowanie częściej, właśnie jako narzędzie wspomagające. Innymi przykładami są R-Soft Studio Sp. zoo w Lublinie i Comarch EZD. Są to także systemy wspierające pracę kancelaryjną w wymiarze tradycyjnym, choć wskazywane przez respondentów jako systemy EZD. Wypłynął stąd wniosek, że nawet, jeśli otrzymano odpowiedzi „TAK (w urzędzie funkcjonuje EZD)”, to w większości przypadków chodziło o system klasy EZD (bez pełnego wdrożenia elektronicznego zarządzania dokumentacją) i narzędzia wspomagające pracę biurową. Sporo też nadeszło odpowiedzi niebudzących wątpliwości - jasno deklarujących korzystanie wyłącznie z narzędzi wspierających ${ }^{32}$.

Celem drugiego projektu, realizowanego przez studentów w semestrze letnim roku akademickiego 2019/2020, było zbadanie liczby wdrożeń i funkcjonowania elektronicznej biurowości także w urzędach podmiotowo określonych przez Rozporządzenie z 2011 r., jednak wyłącznie na terenie województwa małopolskiego $^{33}$. Na badanie odpowiedziało 18 starostw powiatowych, z czego połowa zadeklarowała korzystanie z EZD, a połowa stwierdziła, że takiego systemu nie

32 Dokumentacja badań prowadzonych w 2019 r. przez studentów kierunku archiwistyka, zarządzanie dokumentacją i infobrokerstwo dotyczących wdrożeń systemów EZD i klasy EZD w jednostkach podmiotowo określonych przez Rozporządzenie z 2011 r., realizowanych pod kierunkiem Doroty Drzewieckiej, mps. w zasobie Katedry Archiwistyki i Nauk Pomocniczych Historii Instytutu Historii i Archiwistyki Uniwersytetu Pedagogicznego w Krakowie.

33 Kwestionariusz został rozbudowany, dodatkowo zawierał pytania dotyczące m.in. planów wdrożeniowych, szkoleń pracowników, kosztów ponoszonych w związku ze stosowaniem systemów teleinformatycznych, zob. Dokumentacja badań prowadzonych w 2019 r. przez studentów kierunku archiwistyka, zarządzanie dokumentacją i infobrokerstwo dotyczących wdrożeń systemów EZD i klasy EZD w jednostkach podmiotowo określonych przez Rozporządzenie z 2011 r., realizowanych pod kierunkiem Doroty Drzewieckiej, mps. w zasobie Katedry Archiwistyki i Nauk Pomocniczych Historii Instytutu Historii i Archiwistyki Uniwersytetu Pedagogicznego w Krakowie. 
posiada. Spośród 14 gmin miejskich w woj. małopolskim (wszystkie udzieliły odpowiedzi na pytania) 9 wskazało, że ma wdrożony system EZD, zaś 5 udzieliło odpowiedzi negatywnej. W badaniu wzięło udział 45 gmin miejsko-wiejskich, z czego 42 urzędy zadeklarowały, że korzystają z systemu EZD, zaś 3 udzieliły odpowiedzi przeczącej. Jeśli chodzi o gminy wiejskie - do badania przystąpiło 95 podmiotów, z czego 45 zadeklarowało korzystanie z EZD, zaś 50 udzieliło odpowiedzi negatywnej. Łącząc wszystkie dane, należy stwierdzić, że adresatami badania było łącznie 198 urzędów, z czego 88 zadeklarowało, że posiada system EZD, zaś 78 urzędów udzieliło odpowiedzi negatywnej. 33 jednostki w ogóle nie odpowiedziały, a 1 urząd nie był w stanie określić, czy posiada system EZD, czy też nie. Także w tym badaniu ważną rolę odegrało pytanie dotyczące producenta systemu. Okazało się bowiem, że spośród jednostek deklarujących korzystanie z systemu EZD, zdecydowana większość wskazała system teleinformatyczny jedynie wspomagający wykonywanie czynności kancelaryjnych ${ }^{34}$.

Wykres 12. Używanie systemu EZD (w \%) w urzędach administracji publicznej w Małopolsce. Stan na 2020 r.

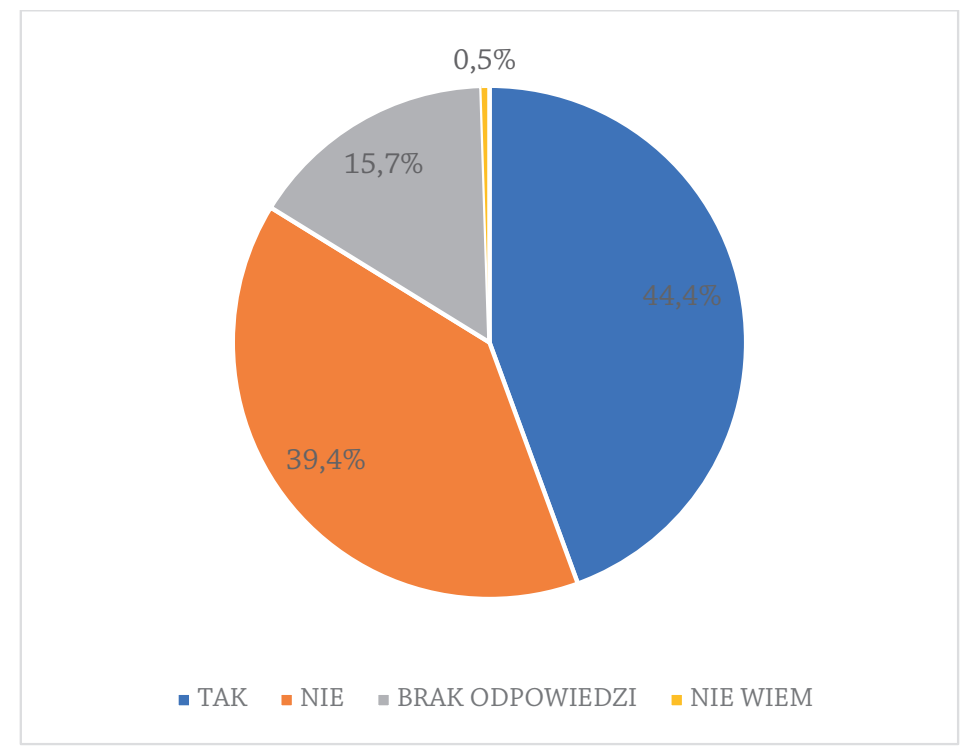

Źródło: zob. przyp. 35.

34 Liderem okazał się system SIDAS EZD firmy MADKOM S.A. Wskazały go 54 badane podmioty. 
Badanie dotyczące wdrażania systemów EZD na terytorium województwa małopolskiego warto skonfrontować z wynikami badań przeprowadzonych przy użyciu innej metodologii, mianowicie analizy protokołów kontroli archiwalnych prowadzonych przez Archiwum Narodowe w Krakowie w latach 2011$2020^{35}$. Badanie to również dotyczy jednostek określonych Rozporządzeniem PRM z 2011 r. Oczywiście trzeba mieć na uwadze, że terytorium podlegające pod nadzór krakowskiego archiwum nie jest zbieżne z granicami województwa małopolskiego ${ }^{36}$.

Wykres 13. Stan posiadania systemu lub narzędzia wspomagającego pracę biurową w latach 2011-2019 z terenu objętego nadzorem archiwalnym przez Archiwum Narodowe w Krakowie

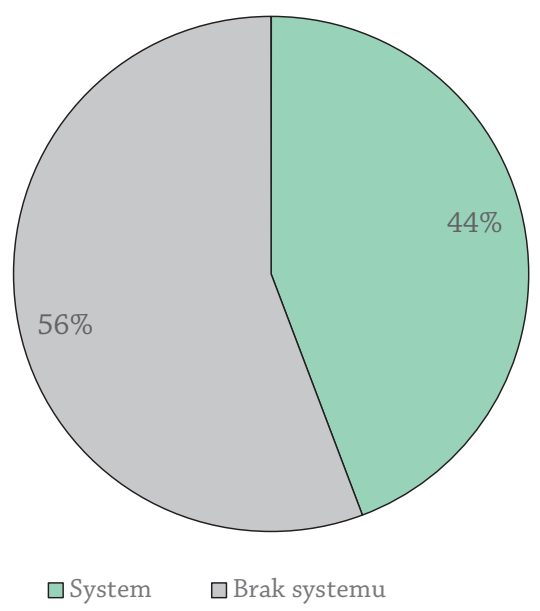

Źródło: zob. przyp. 35.

Analizie poddano dane dotyczące 156 jednostek ze 124 miejscowości należących do województw małopolskiego oraz - w mniejszym zakresie - podkarpackie-

35 Archiwum Narodowe w Krakowie, Protokoły kontroli przestrzegania przepisów o narodowym zasobie archiwalnym i archiwach (Protokoły kontroli archiwum zakładowego) z lat 2011-2020 dotyczące jednostek administracji publicznej podlegających pod Rozporządzenie PRM z 2011 r. z terenu objętego nadzorem archiwalnym przez Archiwum Narodowe w Krakowie.

36 Zgodnie z Rozporządzeniem Ministra Kultury i Dziedzictwa Narodowego z dnia 20 października 2015 r. w sprawie klasyfikowania i kwalifikowania dokumentacji, przekazywania materiałów archiwalnych do archiwów państwowych i brakowania dokumentacji niearchiwalnej (Dz. U. 2015, poz. 1743). 
go i świętokrzyskiego. Otrzymano 246 wyników z okresu 10-letniego, niektóre jednostki były bowiem badane wielokrotnie. Ponad połowa występujących w badaniu jednostek to urzędy gminy (54,5\% | 85). Prawie jedną piątą stanową urzędy miasta (19,9\% | 31). Ponad 8\% badanych jednostek to starostwa (13) a 7,7\% urzędy miasta i gminy (12). W tym badaniu uwzględniono również związki gmin, wojewódzkie i powiatowe inspektoraty oraz Małopolski Urząd Wojewódzki w Krakowie.

Z analizy protokołów jasno wynika, że niespełna połowa (69) badanych jednostek organizacyjnych ma w pewnym stopniu zinformatyzowaną biurowość, zaś w 87 jednostkach nie znajdziemy informacji o jakimkolwiek systemie czy narzędziu.

Wykres 14. Stan posiadania systemu dokumentowania spraw określonego jako podstawowy lub wspomagający w latach 2011-2019 z terenu objętego nadzorem archiwalnym przez Archiwum Narodowe w Krakowie

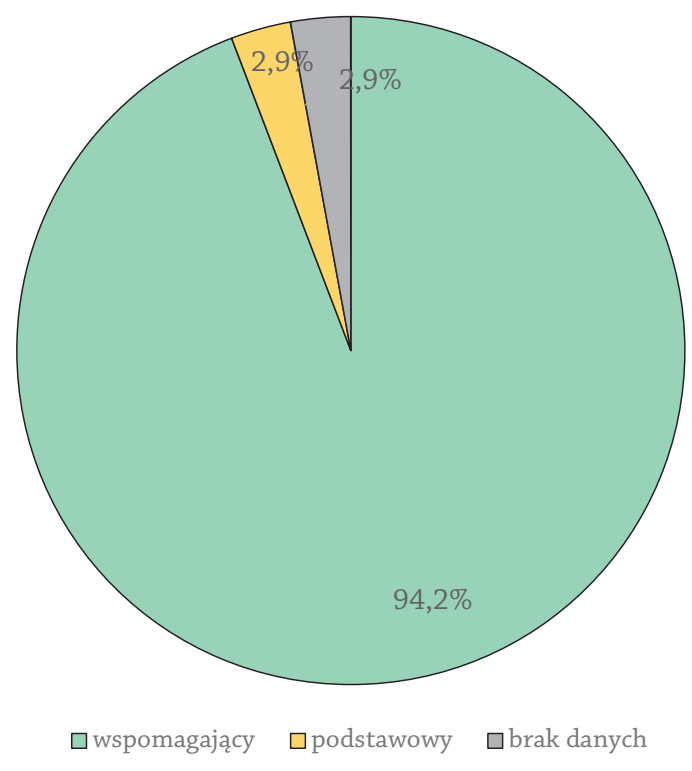

Źródło: zob. przyp. 35.

Spośród jednostek posiadających jakikolwiek system/narzędzie tylko dwie instytucje (Małopolski Urząd Wojewódzki oraz Starostwo Powiatowe w Proszowicach) mają system będący podstawowym sposobem dokumentowania spraw 
(odpowiednio system EZD PUW oraz EZD SIDAS $\left.{ }^{37}\right)$. W pozostałych $65(94,2 \%)$ instytucjach określono go jako wspomagający. W tej liczbie mieszczą się różnego typu produkty - od systemów elektronicznego obiegu dokumentacji, po pojedyncze narzędzia, skoncentrowane na jedno, konkretne zadanie kancelaryjne, np. elektroniczne dzienniki wpływu.

Przechodząc do konkluzji, należy raz jeszcze przypomnieć cel artykułu, którym jest próba pokazania liczby rzeczywistych wdrożeń systemu EZD w polskich urzędach oraz próba interpretacji różnic w wynikach badań prowadzonych przez wybrane instytucje przy użyciu niejednorodnych metod badawczych. Poza tym badanie miało na celu pokazanie zjawiska nadinterpretowania przez producentów, a nierzadko także samych urzędników, funkcjonalności narzędzi informatycznych wspomagających pracę kancelaryjną.

Biorąc pod uwagę wyniki badań przeprowadzonych na zlecenie resortu cyfryzacji oraz przez Główny Urząd Statystyczny, mamy do czynienia z dość nieprecyzyjnymi danymi, przede wszystkim z powodu niejednorodności podmiotów biorących udział w badaniach w poszczególnych latach. Spadek lub wzrost udziału urzędów stosujących EZD może być wynikiem charakteru grupy badawczej, w której znalazły się urzędy niewystępujące w poprzednich edycjach badania.

Wyniki pokazały, że w polskich urzędach administracji publicznej dominuje system tradycyjny, choć nie ma miarodajnych opracowań dotyczących liczby wdrożeń systemu EZD. Przy analizowaniu wyników trzeba wziąć pod uwagę wyżej opisane zasady mówiące, że system EZD nie ma charakteru wspomagającego w kancelarii tradycyjnej, tylko charakter podstawowy, a więc całość dokumentacji jest prowadzona i przechowywana w systemie w postaci elektronicznej. Charakter wspomagający mogą mieć jedynie narzędzia informatyczne w systemie tradycyjnym, służące m.in. do przyjmowania, rejestracji i obiegu korespondencji. Zarówno badania na zlecenie resortu cyfryzacji, Głównego Urzędu Statystycznego, jak i projekty studenckie prowadzono przy użyciu przede wszystkim metod typowych dla nauk społecznych (ankiety). Odpowiedzi udzielone przez respondentów zapewne mają różny poziom precyzyjności. Być może powodem tego zjawiska są nazwy systemów, które często zawierają skrót „EZD”. Interpretacja odpowiedzi pokazała, że to sami urzędnicy nieświadomie błędnie określają mianem systemów EZD systemy wspomagające. Do takich wniosków można dojść, analizując

37 W protokołach wskazano, że system EZD SIDAS jest podstawowym systemem wykonywania czynności kancelaryjnych, dokumentowania przebiegu załatwiania spraw oraz gromadzenia i tworzenia dokumentów elektronicznych. 
odpowiedzi na pytania o moduł archiwum zakładowego oraz szczegółowe hasła z jednolitych rzeczowych wykazów akt, dla których wykonuje się czynności w systemie EZD. W tym miejscu znów należy podkreślić powszechne występowanie terminu „system klasy EZD”, co może przyczyniać się do błędnych przekonań. Lokalne działania urzędników i firm informatycznych dążących do wykorzystania nowych technologii w biurowości spowodowały komplikacje w standaryzacji elektronicznej biurowości, nawet w instytucjach tego samego szczebla administracji.

Za zdecydowanie bardziej miarodajne źródło można uznać protokoły kontroli archiwów zakładowych stworzone przez pracowników Archiwum Narodowego w Krakowie, ale i one potwierdzają popularność systemów tradycyjnych z wykorzystaniem teleinformatycznych narzędzi wspomagających.

Trzeba mieć na uwadze, że wdrażanie narzędzi klasy EZD, wspomagających, bez pełnego wdrożenia elektronicznego zarządzania dokumentacja, może okazać się bezzasadnym wydatkiem finansowym. Poza tym taki system pracy, stanowiący duże obciążenie dla personelu urzędu, jest po prostu nieefektywny. Pracownicy wykonują bowiem te same czynności kancelaryjne na papierze oraz w systemie teleinformatycznym (co zresztą także potwierdzają wyniki badań prowadzonych na zlecenie resortu cyfryzacji) ${ }^{38}$.

Czym można uzasadnić zjawisko niewielkiej popularności EZD? Powodów zapewne jest kilka. Urzędnicy często wskazywali, że nie jest to sprawa priorytetowa dla jednostki oraz że brakuje odpowiednich funduszy na tego typu przedsięwzięcia. Spora część respondentów wskazała też brak racjonalności wdrożenia systemu (nie wszystkie sprawy można cyfryzować, w urzędzie w obiegu jest niewielka liczba pism itp. ${ }^{39}$. Wskazać można także zjawisko inercji wśród pracowników ${ }^{40}$ oraz brak odpowiedniego przygotowania informatycznego. Powodem może być ponadto, wspomniany już, przepis prawa zakazujący powrotu do systemu tradycyjnego w sytuacji, gdy wskazano system EZD jako podstawowy ${ }^{41}$.

Jak można zauważyć, wyniki wszystkich badań są rozbieżne i oscylują w granicach 50-70\% jednostek, w których wdrożono jakikolwiek system. Da się to wytłumaczyć metodologią badań i ich zakresem geograficznym. Co martwi,

\footnotetext{
E. Perłakowska, Systemy zarzq̨dzania dokumentacją w urzędzie..., s. 75.

Zob. przyp. 22.

40 D. Drzewiecka, EZD a dydaktyka - łatwe w teorii, trudne w praktyce. Refleksje nad zagadnieniem wspótpracy jednostek komercyjnych i uniwersytetów, „Archiwista Polski” 2014, nr 3, s. 57-58.

41 Instrukcja kancelaryjna - Załącznik nr 1 do Rozporządzenia PRM z 2011 r. § 1.4.
} 
to wspomniana już niewielka liczba wdrożeń systemu EZD jako podstawowego. Na co dzień dostrzegamy korzystne zmiany np. w usprawnianiu kontaktu w relacji urząd-obywatel, czyli przy wszczynaniu i kończeniu sprawy. Patrząc kompleksowo i uśredniając dane dotyczące informatyzacji biurowości polskich urzędów, można dojść do wniosku, że od kilkunastu lat nie korzystają one z istniejących możliwości i w większości przypadków systemy teleinformatyczne to tylko kosztowna ciekawostka używana sporadycznie lub przez pojedynczych urzędników. Może w partykularnych przypadkach da się zauważyć pozytywny wpływ zdobyczy techniki na współczesną kancelarię, jednak całościowo informatyzację polskiej biurowości - niejednokrotnie bardzo pracochłonną i kosztochłonną - można uznać za niewiele więcej niż tylko pozorną. Jeśli w podmiocie nie ma systemu pozwalającego na kompleksowe zarządzanie, na tworzenie akt sprawy w formie elektronicznej, funkcjonowanie elektronicznego archiwum zakładowego, dokumentację trzeba będzie wydrukować, by móc ją (kat. A) przekazać do archiwum państwowego. Innym jeszcze problemem jest integracja systemów dziedzinowych i dedykowanych, które też powinny pozwalać na łączenie dokumentacji w akta sprawy, bezpieczne jej przechowywanie, udostępnianie, brakowanie lub przekazywanie do właściwego archiwum. Póki co dostrzegalny jest brak kompatybilności i interoperacyjności systemów teleinformacyjnych funkcjonujących w polskiej administracji publicznej, a do zmiany takiego stanu rzeczy jeszcze daleka droga ${ }^{42}$.

\section{Źródła}

Informacja nr 6 Naczelnej Dyrekcji Archiwów Państwowych z dnia 19 kwietnia 2011 r. w sprawie zakresu podmiotowego Rozporządzenia Prezesa Rady Ministrów z dnia 18 stycznia 2011 r. w sprawie instrukcji kancelaryjnej, jednolitych rzeczowych wykazów akt oraz instrukcji w sprawie organizacji i zakresu działania archiwów zakładowych (Dz. U. nr 14, poz. 67 i nr 27, poz. 140), https://www.archiwa.gov.pl/images/docs/instrukcje/06_informacja_nr_6.pdf [dostęp: 23.04.2021].

Protokoły kontroli przestrzegania przepisów o narodowym zasobie archiwalnym i archiwach (Protokoły kontroli archiwum zakładowego) z lat 2011-2020 dotyczące jednostek administracji

42 Zob. D. Makowski, op.cit., s. 441-442. 
publicznej podlegających pod Rozporządzenie PRM z 2011 r. z terenu objętego nadzorem archiwalnym przez Archiwum Narodowe w Krakowie, Archiwum Narodowe w Krakowie.

Rozporządzenie Ministra Kultury i Dziedzictwa Narodowego z dnia 20 października 2015 r. w sprawie klasyfikowania i kwalifikowania dokumentacji, przekazywania materiałów archiwalnych do archiwów państwowych i brakowania dokumentacji niearchiwalnej (Dz. U. 2015, poz. 1743).

Rozporządzenie Ministra Spraw Wewnętrznych i Administracji z dnia 2 listopada 2006 r. w sprawie wymagań technicznych formatów zapisu i informatycznych nośników danych, na których utrwalono materiały archiwalne przekazywane do archiwów państwowych (Dz. U. 2006, nr 206, poz. 1519).

Rozporządzenie Ministra Spraw Wewnętrznych i Administracji z dnia 30 października 2006 r. w sprawie niezbędnych elementów struktury dokumentów elektronicznych (Dz. U. 2006, nr 206, poz. 1517).

Rozporządzenie Ministra Spraw Wewnętrznych i Administracji z dnia 30 października 2006 r. w sprawie szczegółowego sposobu postępowania z dokumentami elektronicznymi (Dz. U. 2006, nr 206, poz. 1518).

Rozporządzenie Prezesa Rady Ministrów z dnia 18 stycznia 2011 r. w sprawie instrukcji kancelaryjnej, jednolitych rzeczowych wykazów akt oraz instrukcji w sprawie organizacji i zakresu działania archiwów zakładowych (Dz. U. 2011, nr 14, poz. 67).

Ustawa z dnia 14 czerwca 1960 r. Kodeks Postępowania Administracyjnego (Dz. U. 1960, nr 30, poz. 168 , z późn. zm.).

Ustawa z dnia 17 lutego 2005 r. o informatyzacji działalności podmiotów realizujących zadania publiczne (Dz. U. 2005, nr 64, poz. 565).

Ustawa z dnia 18 września 2001 r. o podpisie elektronicznym (Dz. U. 2001, nr 130, poz. 1450).

Ustawa z dnia 6 września 2001 r. o dostępie do informacji publicznej z dnia 6 września 2001 r. (Dz. U. 2001, nr 112, poz. 1198).

\section{Bibliografia}

Archiwa Państwowe. EZD informacje ogólne, https://www.archiwa.gov.pl/pl/772-ezd-informacje-ogólne [dostęp: 20.04.2021].

Czerniak S., Orszulak J., Dokument elektroniczny. Przewodnik i katalog dobrych praktyk, Warszawa 2017.

DMS, EZD, eSOD - różne nazwy, jeden system, www.progmate.pl/pl/articles/differentnames [dostęp: 25.01.2021]. 
Dokumentacja badań prowadzonych w 2019 r. przez studentów kierunku archiwistyka, zarządzanie dokumentacją i infobrokerstwo dotyczących wdrożeń systemów EZD i klasy EZD w jednostkach podmiotowo określonych przez Rozporządzenie z 2011 r., realizowanych pod kierunkiem Doroty Drzewieckiej, mps. w zasobie Katedry Archiwistyki i Nauk Pomocniczych Historii Instytutu Historii i Archiwistyki Uniwersytetu Pedagogicznego w Krakowie.

Dokumentacja badań prowadzonych w 2020 r. przez studentów kierunku archiwistyka, zarządzanie dokumentacją i infobrokerstwo dotyczących wdrożeń systemów EZD i klasy EZD w jednostkach podmiotowo określonych przez Rozporządzenie z 2011 r. z terenu woj. małopolskiego, realizowanych pod kierunkiem Doroty Drzewieckiej, mps. w zasobie Katedry Archiwistyki i Nauk Pomocniczych Historii Instytutu Historii i Archiwistyki Uniwersytetu Pedagogicznego w Krakowie.

Drzewiecka D., EZD a dydaktyka - łatwe w teorii, trudne w praktyce. Refleksje nad zagadnieniem wspótpracy jednostek komercyjnych i uniwersytetów, „Archiwista Polski” 2014, nr 3, s. 57-62.

Drzewiecka D., Mapa topograficzna systemów EZD w Polsce (prezentacja i komentarz do prezentacji), ResearchGate. Dorota Drzewiecka, https://www.researchgate.net/profile/Dorota-Drzewiecka [dostęp: 26.06.2021].

Drzewiecka D., [rec.:] Grzegorz Abgarowicz, Ewa Perłakowska, Artur Prasal, Procedury elektronicznego zarządzania dokumentacją w administracji, Wydawnictwo C.H. Beck, Warszawa 2018, ss. 322, „Archeion" 2019, t. 120, s. 406-412.

Drzewiecka D., Karaś T., Wdrażanie systemu elektronicznego obiegu dokumentacji w Urzędzie Miasta Krakowa - wybrane problemy, [w:] Rola archiwów w procesie wdrażania systemów elektronicznego zarządzania dokumentacją. $Z$ doświadczeń archiwów szkół wyższych, instytucji naukowych i kulturalnych oraz państwowych i samorządowych jednostek organizacyjnych, red. A. Barciak, D. Drzewiecka i K. Pepłowska, Katowice 2018, s. 57-75.

Elektroniczne zarządzenie dokumentacją. Partnerzy w liczbach, https://ezd.gov.pl/www/ezd/partnerzy [dostęp: 18.06.2021].

Główny Urząd Statystyczny, Społeczeństwo informacyjne w Polsce. Wyniki badań statystycznych z lat 2014-2018, https://stat.gov.pl/obszary-tematyczne/nauka-i-technika-spoleczenstwo-informacyjne/spoleczenstwo-informacyjne/spoleczenstwo-informacyjne-w-polsce-wyniki-badan-statystycznych-z-lat-20142-018,1,12.html [dostęp: 12.04.2021].

Główny Urząd Statystyczny, Społeczeństwo informacyjne w Polsce w 2020 r., https://stat.gov.pl/obszary-tematyczne/nauka-i-technika-spoleczenstwo-informacyjne/spoleczenstwo-informacyjne/spoleczenstwo-informacyjne-w-polsce-w-2020-roku,1,14.html [dostęp: 12.04.2021].

Makowski D., Archiwa a systemy informatyczne w administracji publicznej. Wstęp do problematyki, „Archeion" 2020, t. 121, s. 411-444. 
Perłakowska E., Elektroniczne zarządzanie dokumentacja, [w:] G. Abgarowicz, E. Perłakowska, A. Prasal, Procedury elektronicznego zarzadzania dokumentacja w administracji, Warszawa 2018, s. 129 186.

Perłakowska E., Systemy zarzq̨dzania dokumentacją w urzędzie, [w:] G. Abgarowicz, E. Perłakowska, A. Prasal, Procedury elektronicznego zarządzania dokumentacja w administracji, Warszawa 2018, s. $55-76$.

Perłakowska E., Zarządzanie dokumentacja w systemie tradycyjnym, [w:] G. Abgarowicz, E. Perłakowska, A. Prasal, Procedury elektronicznego zarzq̨dzania dokumentacja w administracji, Warszawa 2018, s. 77-127.

Program Zintegrowanej Informatyzacji Państwa na lata 2014-2022, https://www.gov.pl/web/cyfryzacja/program-zintegrowanej-informatyzacji-panstwa [dostęp: 26.06.2021].

Robótka H., Archiwa cyfrowe i cyfrowi archiwiści w świetle nauki i wybranych dokumentów. Rozważania czysto teoretyczne, [w:] „Archiwista cyfrowy” i infobroker - kształcenie, sylwetka, wyzwania, red. D. Drzewiecka i B. Drzewiecki, Kraków 2016, s. 13-24.

Robótka H., Zarządzanie dokumentacjq w dobie informatyzacji, [w:] Zarządzanie dokumentacjq w instytucji. Czynniki Sprzyjające i ograniczenia, Biblioteka Zarządcy Dokumentacji, t. 9, red. R. Degen i M. Jabłońska, Toruń 2020, s. 97-116.

Robótka H., Zarzq̨dzanie dokumentacją w podmiocie (organizacji, instytucji, u aktotwórcy). Wprowadzenie do tematyki, [w:] Zarzadzanie dokumentacją. Badania i dydaktyka, Biblioteka Zarządcy Dokumentacji, t. 7, red. R. Degen i M. Jabłońska, Toruń 2016, s. 11-36.

Serwis Rzeczypospolitej Polskiej. EZD RP - elektroniczne zarządzanie dokumentacją w administracji, archiwum.mc.gov.pl/konsultacje/program-zintegrowanej-informatyzacji-panstwa/ezd-rp-elektroniczne-zarzadzanie-dokumentacja-w-administracji [dostęp: 26.06.2021].

Wpływ cyfryzacji na działanie urzędów administracji publicznej w Polsce w 2012 r. - badanie wykonane na zlecenie Ministerstwa Administracji i Cyfryzacji przez firmę Partner in Business Strategies, październik 2012 r., https://dane.gov.pl/media/resources/20140505/PBSMACCyfryzacjafullPL-2012.pdf [dostęp: 25.01.2021].

Wpływ cyfryzacji na działanie urzędów administracji publicznej w Polsce w 2013 r. - badanie wykonane na zlecenie Ministerstwa Administracji i Cyfryzacji przez firmę Partner in Business Strategies, grudzień 2013 r., https://dane.gov.pl/media/resources/20140502/PBSMACCyfryzacja11122013.pdf [dostęp: 25.01.2021].

Wpływ cyfryzacji na działanie urzędów administracji publicznej w Polsce w 2014 r. - badanie wykonane na zlecenie Ministerstwa Administracji i Cyfryzacji przez firmę Partner in Business Strategies, grudzień 2014 r., https://dane.gov.pl/media/resources/20150227/PBSMACCyfryzacjaFIN2014.pdf [dostęp: 25.01.2021]. 
Wpływ cyfryzacji na działanie urzędów administracji publicznej w Polsce w 2015 r. - badanie wykonane na zlecenie Ministerstwa Cyfryzacji przez ASM - Centrum Badan i Analiz Rynku, https:// dane.gov.pl/media/resources/20160907/raportwplywcyfryzacjinadzialanieurzedowadministracjipublicznejwpolscew2015r.-wcag0.pdf [dostęp: 25.01.2021].

Wspótczesna biurowość w administracji publicznej. Komentarz do instrukcji biurowej Prezesa Rady Ministrów z 2011 r., Biblioteka Zarządcy Dokumentacji, t. 4, red. H. Robótka, Toruń 2013. 